\title{
Üretim İşletmelerinde Maliyet Muhasebesi Kullanım Düzeyinin Ölçülmesine Yönelik Bir Araştırma: Tokat İli Örneği
}

\author{
A Research on The Measurement of Cost Accountancies Usage Level in Production \\ Operations: Tokat Regional Sample
}

\author{
Dr. Öğr. Üyesi Ergin TEMEL (iD) 1
}

\begin{abstract}
$\ddot{O} \mathbf{z}$
Yoğun rekabetin yaşandığı günümüz iş dünyasında yöneticilerin, doğru kararlar alabilmesi için, doğru, geçerli, güvenilir ve zamanlı bilgiye ihtiyaç vardır. Maliyet muhasebesi hem hizmet işletmelerinde hem de üretim işletmelerinde yöneticilerin karar vermelerinde en önemli bilgi kaynağıdır. Yöneticilerin ihtiyaç duyacağı maliyet verilerinin elde edilmesi için işletmede etkin bir maliyet muhasebe sisteminin kurulmuş olması gerekmektedir. Bu çalışmanın amacı, Tokat ilinde faaliyet gösteren anonim ve limitet şirket statüsündeki üretim işletmelerinde maliyet muhasebesi sisteminin kullanım düzeyinin ölçümünü yapmaktır. Araştırma verilerinin elde edilmesinde araştırma yöntemlerinden biri olan anket yöntemi kullanılmıştır. Araştırmanın verileri Tokat il merkezi ve ilçelerinde faaliyet gösteren üretim işletmelerinden elde edilmiştir. Araştırmanın sonucunda işletmelerin maliyet muhasebesi kullanım düzeyinin farklılık gösterdiği, işletmelerde yeteri düzeyde ayrı bir maliyet muhasebesi bölümünün olmadığı, yöneticilerin maliyet muhasebesi ile ilgili eğitim alma oranın çok düşük olduğu tespit edilmiş̧ir.
\end{abstract}

Anahtar Kelimeler: Maliyet muhasebesi, üretim işletmeleri, maliyet muhasebesi kullanımı

Makale Türü: Araştırma

\begin{abstract}
In today's labor market where there is intense competition, managers need accurate, valid, reliable and timely information in order to make the right decisions. Cost accounting is the most important source of information for managers' decision making in both service businesses and production enterprises. An effective cost accounting system must be established in the enterprise in order to obtain the cost data that managers will need. The aim of this study is to measure the level of use of cost accounting in production enterprises operating in Tokat. Questionnaire method was used to obtain research data. The data of the research were obtained from the production enterprises operating in Tokat provinces and districts. As a result of the research, it was determined that the level of use of cost accounting of enterprises differed, there was not a separate cost accounting department at a sufficient level, and the rate of training on cost accounting was insufficient.
\end{abstract}

Keywords: Cost accounting, production enterprises, use of cost accounting

Paper Type: Research

\footnotetext{
${ }^{1}$ Tokat Gaziosmanpaşa Üniversitesi, Erbaa Sağlık Bilimler Fakültesi, ergin.temel@gop.edu.tr.

Atıf için (to cite): Temel, E. (2020). Üretim işletmelerinde maliyet muhasebesi kullanım düzeyinin ölçülmesine yönelik bir araştırma: Tokat ili örneği. Afyon Kocatepe Üniversitesi Sosyal Bilimler Dergisi, 22(4), 1107-1123.
} 


\section{Giriş}

Maliyet muhasebesi verileri yöneticilerin doğru karar almalarındaki bilgi kaynağıdır. $\mathrm{Bu}$ bilgi kaynağının doğru, geçerli, güvenilir ve zamanlı bilgi üretmesi için işletmenin muhasebe sisteminde yer almas1 gerekir. Maliyet muhasebesi ile üretilen mamul veya hizmetin birim maliyeti, mamul veya yarı mamul stok değerleri, satış fiyatı, özel kararların alınmasında kullanılacak maliyet verileri, gelecekle ilgili planlarda kullanılacak maliyet verileri gibi birçok karar alma verisi elde edilmektedir.

Yoğun rekabetin yaşandığı günümüz iş dünyasında yöneticilerin önemli sorunlarından biri de maliyetlerini yönetebilmeleri için gerekli bilgileri etkin bir şekilde kullanamamalarıdır. Etkin bir maliyet yönetimi için işletmelerin maliyet verilerini elde edecekleri maliyet muhasebesi bilgi sistemini işletme organizasyonunda oluşturması gerekmektedir.

$\mathrm{Bu}$ çalışma, Tokat ilinde faaliyet gösteren anonim ve limitet şirket statüsündeki üretim işletmelerinde maliyet muhasebe sistemini kullanma düzeylerini ölçmek amacıyla yapılmıştır. Çalışma ile Tokat ilindeki üretim işletmelerinde ayrı bir maliyet muhasebesi bölümünün varlığı, maliyetlerin takibi için gider yeri ayrımı, stok değerleme yöntemleri, fiyatlandırma politikaları, sabit ve değişken maliyetlerin maliyet hesaplamadaki kullanımı, maliyetleri mamullere yüklerken kullandıkları faaliyet hacimleri, bütçe hazırlama durumları, fireleri dikkate almaları, üretilen mamullerdeki maliyet etkenlerinin payı gibi maliyet muhasebesi kullanımına yönelik durumları anket yöntemi kullanılarak tespit edilmiştir.

\section{Kavramsal Çerçeve}

Araştırma çerçevesinde maliyet muhasebesiyle ilgili kullanılan kavramlar şöyledir;

\subsection{Maliyet Muhasebesi Sistemi ve Önemi}

Maliyet muhasebesi, üretimi yapılan mal ve hizmetlerle ilgili saptanan maliyetlerin birim ve toplam maliyetlere aktarılmak suretiyle, maliyetlerin hesaplanmasına, kontrolüne, planlanmasına, analiz edilmesine ve satış tutarının saptanmasına olanak sağlayan bilgileri yönetime yardımcı olacak şekilde üreten ve kayıtlayan içe dönük muhasebe türü olarak tanımlanmaktadır (Özulucan, 2019, s. 8). İşletme yönetimi maliyet muhasebesini, birim maliyetleri tespit etmek, işletme faaliyetlerini kontrol etmek, planlamaya yardımcı olmak ve özel kararların alınmasında yardımcı olması (Bursal ve Ercan, 1997, s. 14) amacıyla kullanmaktadır.

Yöneticilerin karar vermede kullanacağı nicel bilgi önemlidir. Nicel bilgiler kullanılarak alınan kararlar daha isabetli olmaktadır. Çünkü nicel bilgiler nitel bilgilere göre daha fazla kesinliği vardır (Ertaş, 2016, s. 7). Karar vermede kullanılacak nicel bilgiler maliyet muhasebesi ile elde edilmektedir. Maliyet muhasebesi bilgileri kullanılarak, üretilen mamulün veya hizmetin maliyeti tespit edilerek satış fiyatı kararları verilir, yarı mamulün maliyeti tespit edilerek mali tablolar hazırlanır. Elde edilen kar maliyet muhasebesi verileriyle tespit edilir. İşletmelerin hazırlayacağı bütçelerde kullanılacak veriler, yatırım kararlarında veya alternatif seçim kararlarında kullanılacak veriler maliyet muhasebesinden elde edilmektedir. Yöneticilerin karar vermede kullanacağ 1 daha birçok maliyet verileri maliyet muhasebesinden elde edildiği için özellikle üretim ve hizmet işletmelerinde maliyet muhasebe sistemine ihtiyaç vardır.

\subsection{Maliyet Unsurları}

Üretilen mamulün maliyeti direkt ilk madde ve malzeme, direkt işçilik ve genel üretim maliyetinden oluşur. Üretilen mamulün temel yapısını oluşturan, her bir mamul için ne kadar tüketildiği doğrudan tespit edilebilen madde ve malzemelerin maliyetine direkt ilk madde ve malzeme maliyeti, üretilen mamulün şekillendirilmesinde direkt etkisi olan ve her bir mamul için ne kadar çalışıldığ doğrudan tespit edilebilen işçiliğin maliyetine direkt işçilik maliyeti, üretimle ilgili olan ancak direkt olarak mamul maliyetine yüklenemeyen üretimle ilgili maliyete de genel üretim maliyeti denir. Endirekt ilk madde ve malzeme maliyeti, endirekt işçilik maliyeti ve 
üretimle ilgili diğer maliyetler (elektrik, su, kira, sigorta, amortisman gibi) genel üretim maliyetlerini oluşturur.

Maliyetler faaliyet hacmiyle duyarlılığına göre, değişken maliyetler, sabit maliyetler ve yarı değişken (karma) maliyetler olarak üç farklı şeklide ortaya çıkar. Değişken maliyetler, faaliyet hacmiyle doğrudan doğruya bağlantılı olarak ortaya çıkan, faaliyet hacminin artmasıyla artış gösteren, azalış gösterdiğinde azalan maliyetlerdir. Sabit maliyetler belli bir zaman aralığında faaliyet hacmi ile birlikte artış veya azalış göstermeyen maliyetlerdir (Ertaş, 2016, s. 27). Yarı değişken (karma) maliyetler hem sabit hem de değişken maliyet özelliklerini birlikte gösteren maliyetlerdir. Yarı değişken nitelikli maliyetlerin bir kısmı faaliyet hacmindeki değişimlerden etkilenirken bir kısmı da etkilenmez (Can, 2006, s. 39).

\section{3. Üretim Yönetimine Göre Maliyet Muhasebe Sistemleri}

Kullanılan üretim yönetimine göre maliyet sistemleri üretimin özelliğine ve üretim politikasına bağlı olarak sipariş, safha ve karma maliyet sistemi olarak üç gruba ayrılır.

Sipariş maliyet sistemi, birbirinden gerek tür gerekse değer olarak farklı ürünlerin üretildiği ve üretim süreçlerinde farklı üretim tekniklerinin kullanıldığ 1 ürünlerin, üretim maliyetlerinin izlenmesinde kullanılan yöntemdir (Abdioğlu, 2013, s. 337). Safha maliyet sistemi, aynı cins, biçim ve aynı özellikteki mal ve hizmetlerin parti halinde ve birbirini takip eden çeşitli üretim safhalarında üretimin yapıldığı durumlarda kullanılan yöntemdir (Atamanalp vd., 2000, s. 67). Bazı işletmelerde üretimlerini ve maliyet takiplerini hem safha hem de sipariş maliyet sistemi kullanarak gerçekleştirmektedir. Sipariş ve safha maliyet sisteminin birlikte kullanıldığ sistemlerde bulunmaktadır. Bu iki sistemin birlikte kullanılarak oluşturulan sisteme karma maliyet sistemi denir (Ertaş, 2016, s. 251).

\subsection{Maliyetlerin Kapsamına Göre Maliyet Sistemleri}

Birim üretim maliyetlerin tespit edilmesinde sabit ve değişken maliyetlerin hesaplamada kullanılmasına göre kullanılan yöntemler, tam maliyet, değişken maliyet, normal maliyet ve asal maliyet yöntemleri olmak üzere dört grupta toplanmaktadır.

Tam maliyet yöntemi, dönemin üretim giderlerinin (direk ilk madde ve malzeme, direk işçilik ve genel üretim giderlerinin) tümünün sabit ve değişken ayrımı yapmaksızın o dönemde üretilen mamul veya hizmetlere yüklemesi yapılarak üretim maliyetlerinin hesaplandığ yöntemdir (Büyükmirza, 2000, s. 466). Normal maliyet yöntemi, dönemin üretim giderlerinden direkt ilk madde ve malzeme, direkt işçilik ve genel üretim giderlerinden değişken kısmının tamamını, sabit genel üretim giderininse sadece kullanılan kapasiteye isabet eden tutarını üretim maliyetine yükleyen yöntemdir (Büyükmirza, 2000, s. 470). Değişken maliyet yönteminde, dönemin üretim giderleri direkt ilk madde ve malzeme, direkt işçilik ve değişken genel üretim giderlerinden oluşur (Ertaş, 2016, s. 252). Direkt maliyet yönteminde, üretimle ilgili sadece direkt ilk madde ve malzeme ile direkt işçilik giderlerinin üretilen mamulün maliyetinde hesaba katılır (Abdioğlu, 2013, s. 22)

\subsection{Birleşik ve Yan Mamul}

Üretim işletmelerinde bir safhada aynı ilk maddelerden üretimin teknik özelliği gereği iki veya daha fazla mamulün zorunlu olarak birlikte üretilmesine birleşik üretim denir (Civelek, 2002, s. 362). Paket süt üretilirken kaymak, şeker üretilirken, küspe ve ispirto üretilmesi, un üretilirken kepek üretimi birleşik üretime örnek gösterilebilir. Birden fazla mamulün zorunlu olarak birlikte elde edildiği bir üretim sürecinin maliyetine de birleşik maliyet denir (Bursal ve Ercan, 1997, s. 317). Birleşik mamullerin ortaya çıkmaya başladığı noktaya ayrılma noktası, ayrılma noktasına kadar üretim bölümünde toplanan bütün maliyetlere de birleşik maliyet denir (Civelek, 2002, s. 362).

Birleşik üretim sonucu elde edilen mamuller, ana mamul ve yan mamul olarak iki sınıfa ayrılır. Ana mamul, aynı üretim işlemeleri ile birlikte birden fazla türde ortaya çıkan, satış değeri 
yüksek olan, yan mamul, ana mamul ile karşılaştırıldığında satış değeri düşük olan mamullere denir (Abdioğlu, 2013, s. 316).

Birleşik mamullerin birim maliyetlerini tespit etmek için birleşik maliyetlerin birleşik mamullere dağıtılması gerekir. Üretimde ortaya çıkan birleşik maliyetler üretilen mamullerin (Ana ve yan mamullerin) ortak maliyeti olduğu için her bir mamule ortak maliyetten pay verilir. Birleşik maliyetlerin mamullere dağıtımı yapılırken, üretim miktarı, direkt işçilik saati, direkt işçilik maliyeti, direkt ilk madde ve malzeme maliyetleri, satış değeri, tahmini net gerçekleşebilir değer, brüt kâr marjı yöntemlerinden biri kullanılabilir.

\subsection{Genel Üretim Maliyetlerinin Dağıtımı}

Genel üretim maliyeti, direkt ilk madde ve malzeme ile direkt işçilik dışında kalıp üretime yardımcı olan endirekt malzeme ve endirekt işçiliklerle diğer bütün endirekt üretim harcamalarıdır (Atamanalp vd., 2000, s. 184). Genel üretim maliyetleri üretilen mamullerle direkt ilişkili olmadığı için üretilen mamullerdeki paylarını doğrudan tespit etmek mümkün olmamaktadır. Genel üretim maliyetlerinin mamullere yüklenmesi geleneksel anlamda üç aşamadan meydana gelir. Birinci aşamada genel üretim maliyetleri gider merkezlerine dağıttlır, ikinci aşamada yardımcı gider merkezlerinde biriken maliyetler doğrudan, kademeli, matematiksel ve planlı dağıtım yöntemlerinden biri kullanılarak esas gider merkezine dağıtılır, üçüncü aşamada esas gider merkezinde toplanan maliyetler üretim miktarı, direkt ilk madde ve malzeme miktarı, direkt ilk madde ve malzeme maliyeti, direkt işçilik saati, makine saati gibi ölçüler kullanılarak üretilen mamullere yüklenir (Can, 2006, s. 99).

\subsection{Mamul Fiyatlama}

Üretilen mamullerin talebine etki edecek etkenlerin başında mamulün fiyatı gelmektedir. İşletmeler üretmiş olduğu mamulleri fiyatlandırmada çeşitli yöntemler kullanmaktadırlar. Mamul fiyatlama için, maliyet odaklı, talep odakl1, rekabet odaklı yöntemler kullanılabilir (Tutkavul ve Elmac1, 2016, s. 664)

\subsection{Fire}

Üretilen mamulün birim maliyetini artıran ve işletmelerin çoğunluğunda ortaya çıkan fire, üretim sırasında kullanılan malzemelerin uçması, çekmesi, tozlaşması veya buharlaşması sonucu üretimden çıkan miktarın, üretime giren miktardan az olmasıyla kendini gösterir (Özkan, 2006, s. 109). Fire, malzeme kalitesizliği, üretimde kullanılan makinenin ayarsızlığı veya uygunsuzluğu, işçi hataları, üretimin vermiş olduğu (buharlaşma, kimyasal reaksiyon, kumaş kırpıntıları gibi) zorunluluk gibi nedenlerle ortaya çıkmaktadır.

Firelerin maliyetlerle ilişkilendirilmesi ve vergi mevzuatı açısından normal ve anormal fire olmak iki gruba ayırmaktadır. Normal fire, normal üretim koşullarında oluşması beklenilen ve kaçınılması mümkün olmayan fireyi, anormal fire ise etkin olmayan üretim sonucunda ortaya çıkan ve normal kabul edilen miktarın üzerinde oluşan fireyi ifade etmektedir (Özulucan, 2010, s. 158-159).

\subsection{Stok Değerleme Yöntemi}

Paranın satın alma gücünde yaşanan değişimi stokların üretimde kullanıldığında hangi fiyatın geçerli olacağı sorununu doğurmuştur. Bu sorunun çözümü için çeşitli stok değerleme yöntemleri geliştirilmiştir. Stokların değerlemesinde kullanılacak yöntemler, gerçek maliyet yöntemi, ortalama maliyet yöntemi, ilk giren ilk çıkar yönetimi, son giren ilk çıkar yöntemi (5024 sayılı enflasyon muhasebesi kanunu ile uygulamadan kaldırılmıştır), en düşük fiyatlı ilk çıar yöntemi, en yükssek fiyatlı ilk çıkar yöntemi, ilk gelecek olan ilk çıkar yöntemi, piyasa fiyatı yöntemi (Abdioğlu, 2013, s. 166) gibi yöntemler kullanılmaktadır. 


\subsection{Bütçe}

Bütçe, rakamlarla ifade edilmiş düzenli bir hareket planı (Büyükmirza, 2000, s. 623) olarak tanımlanabilir. İşletmelerin planlarını uygularken katlanacakları giderlerin bugünden tespit edilmesi bütçeler yardımıyla yapılmaktadır. İşletmeler, satış, üretim, işçilik, stok, nakit, yatırım gibi çeşitli bütçeler hazırlayarak faaliyet planlarını sayısallaştırırlar. İşletmelerin maliyet muhasebesini kullanma amaçlarından biri de bütçelerin hazırlanmasına yardımcı olmasıdır. Maliyet muhasebesi verileri kullanılarak işletme bütçeleri hazırlanmakta ve bütçelerle gelecekle ilgili planlar sayısallaştırılmaktadır.

\subsection{Gider Yeri}

Gider yeri, giderlerin ayrı olarak izlenmesine imkân veren örgüt veya hesap birimlerine denir (Büyükmirza, 2000, s. 169). Üretim işletmelerinde üretim süresince çeşitli giderler meydana gelmektedir. Bu giderlerin meydana geldiği fabrika içerisindeki yerler gider yeri olarak ifade edilmektedir. Üretime vermiş olduğu katkıya ve işletmelerin özelliklerine göre işletmelerde çeşitli gider merkezleri bulunmaktadır. Üretimdeki etkisine göre, esas, yardımcı, hizmet gider merkezleri, yapılan işin özelliğine göre de kesim, dikim, boya, 1sı merkezi, enerji merkezi, kalite kontrol gibi gider merkezleri bulunmaktadır.

\section{Literatür Araştırması}

Ayyıldız ve Durna (2005), Kayseri ilinde maliyet muhasebesi kullanımına ilişkin araştırma yapmışlardır. Araştırma 30 işletme ile yapılmış ve araştırma sonucunda, Muhasebe Uygulamaları Genel Tebliği ve TDHP 7/A kayıt ortamının da etkisi ile maliyet muhasebesinin özellikle kayıt düzeni için getirdiği uygulamalar ile raporlamaya esas olan maliyet bilgilerinin elde edilebildiği, ancak bazı kavram ve tanımların anlaşılmadığı, üretime eş zamanlı, güncel maliyet bilgilerinden yararlanılmadığı sonucuna varmışlardır.

Antony ve Kumar (2005) Çalışmalarında, İngiltere'de küçük ve orta ölçekli işletmelerde altı sigma uygulamasını analizini yapmayı amaçlamışlardır. Çalışmanın sonucunda, KOBI'lerin çoğunun altı sigmanın farkında olmadığını ve birçoğunun altı sigma projesini uygulamak için kaynaklara sahip olmadığını tespit etmişlerdir. Altı sigmanın KOBİ'ler arasında genel olarak popüler olmadığını da tespit etmişlerdir.

Özkan (2006), sanayi işletmelerinde uygulanan maliyet muhasebesi politikalarının araştırılması, Kayseri örneği başlıklı çalışmada 150 'den fazla çalışanı olan 31 işletmeye uygulamış ve araştırmanın sonucunda, bazı politikaların işletmelerde yoğunlukla uygulandığı, bazı politikaların uygulanmasında dağınıklık olduğu, aynı sektörde faaliyet eden işletmelerde dahi farklı politikaların tercih edildiği tespit etmiştir.

Dönmez ve diğerleri (2006), yönetim muhasebesinin kavramsal gelişim surecini değerlendirmiş, Ersoy ve diğerleri (2006), İSO'nun İlk 500 giren üretim işletmelerinde geleneksel ve çağdaş maliyet / yönetim muhasebesi sistemlerinin uygulanmasına yönelik araştırma yapmışlardır. Yüzbaşığlu (2004), stratejik yönetim ve planlama açısından stratejik maliyet yönetimi ve enstrümanlarını incelemiştir. Yükçü ve atağan (2012), maliyet muhasebesinin tarihi gelişimini incelemiş̧lerdir

Uyar (2008), Denizli ilinde faaliyet gösteren üretim işletmelerinde maliyet muhasebesi uygulama düzeylerinin ölçmek amacıyla 86 işletme ile anket yöntemini kullanarak çalışma yapmıştır. Araştırmada, Denizli'de işletmelerin genelde tekstil, konfeksiyon, dokuma ve boya sanayinde faaliyet gösterdikleri, işletmelerde kurumsal yapının henüz oluşmadığı, maliyetlerin genelde aylık olarak hesaplandığ 1 , fiili maliyet yöntemini tercih ettiklerini, karar vermede tam maliyet yöntemini tercih ettiklerini, maliyet unsurları arasında en önemli payın direkt ilk madde ve malzeme olduğu, işletmelerin büyük çoğunluğunun mamul ve bölüm karlılığını analiz ettikleri sonuçlarına varmıştır. 
Tekşen ve Kalkan (2012), yönetim kararlarında muhasebe bilgi sisteminin etkisi: batı Akdeniz bölgesinde faaliyette bulunan mermer işletmeleri üzerine bir araştırma yapmışlar ve araştırmanın sonuncunda, muhasebe bilgilerinin yönetim kararlarına etkisini \% 74,97 oranında ölçtüğü sonucuna varmışlardır.

Tanç (2012), otel işletmelerinde yönetim muhasebesi uygulamalarını tespit etmeye yönelik araştırmasını Kapadokya bölgesinde uygulamıştır. Araştırmanın sonucunda, Kapadokya bölgesinde yer alan otellerde maliyet ve yönetim muhasebesi sistemlerinin etkin olarak kullanılmadığı sonucuna varmıştır.

Tugay ve Akın (2013), üretim işletmelerinde maliyet muhasebesi uygulama düzeyini Burdur ili için incelemiş ve araştırmada, işletmelerin yeterince kurumsallaşamadıkları ve bu nedenle maliyet muhasebesinin ürettiği bilgilerin yönetim kararlarında kullanılması konusunda yeterli farkındalıklarının oluşmadığı sonucuna varmışlardır.

Mărginean'in (2013) Romanya'da mobilya sanayinde bir işletmede standart maliyet sisteminin uygulanabilirliğine yönelik bir çalışma yapmıştır. Romanya'daki mobilya sektöründeki işletmeler için maliyet yönetim sürecinde uygulanabilir olduğu sonucuna varmıştır.

Görmüş ve diğerleri (2015), yönetimin etkinliği açısından standart maliyet yönteminin Uygulanması başlıklı çalışmalarında uşak ilinde orta ölçekli işletmelerde standart maliyet yönteminin uygulanabilirliği araştırılmıştır. Araştırmada, bir fabrika için standart maliyet yönteminin uygulanmıştır. Araştırmanın sonucunda direkt ilk madde ve malzeme maliyetinde 3.537,0075 TL olumsuz sapma, direkt işçilik maliyetinde 192,322 TL olumlu sapma, genel üretim maliyetinde 913,760 TL olumsuz sapma olduğunu tespit etmişlerdir.

Yürekli (2017), KOBİ'lerde yönetim ve maliyet muhasebesinin stratejik karar alma üzerindeki etkisini incelemiş ve KOBİ'lerin stratejik kararlarında yönetim muhasebesinin maliyet muhasebesine göre daha etkin kullanıldığı sonucuna ulaşmıştır.

\section{Uygulama}

Bu bölümde, Tokat ilinde faaliyette bulunan üretim işletmelerinin maliyet muhasebesini kullanma düzeylerini belirlemek için yapılan araştırmanın bulguları değerlendirilmiştir.

Tokat, 620.000 nüfusuyla orta Karadeniz bölgesinde yer alan, verimli topraklarıla bölgenin ve ülkenin tarımsal ürün yetiştirmede önemli bir yere sahip olan ilidir. Tokat ilinde sanayi adına 1930 yılında kurulan Türkiye'nin ilk şeker fabrikalarından olan Turhal şeker ve makine fabrikası sanayi sektörünün başlangıcını oluşturmuştur. 1985 yılından sonra uygulanan teşviklerle Tokat merkez ve ilçelerinde özel sektöre ait çok sayıda üretim işletmesi kurulmuştur. Tokat merkez ve ilçelerinde sanayi kollarının meyve suyu, süt ve süt ürünleri, un ve yem, tuğla ve kiremit, kireç, orman ürünleri, tekstil, beton, çimento, metal, zirai alet gibi üretim yapan fabrikalar bulunmaktadır (http://www.tokattso.org.tr/?pnum=59\&pt=Tokat+Ekonomisi, 30.08.2020).

\subsection{Araştırmanın Amacı}

Bu çalışmanın temel amacı, Tokat merkez ve ilçelerinde faaliyet gösteren anonim ve limitet şirket statüsündeki üretim işletmelerinin maliyet muhasebesi kullanma düzeylerini tespit etmektir.

\subsection{Araștırmanın Yöntemi}

Araştırmada veri toplama yöntemi olarak anket yönteminden yararlanılmıştır. Anket formunda iki kısımda toplam 27 soru bulunmaktadır. Anketin ilk bölümünde işletmelerin genel özelliklerini belirlemeye yönelik sorular, ikinci bölümde de maliyet muhasebesini kullanma düzeylerini ölçecek sorular yer almıştır. Ankette, üretim işletmelerinde ayrı bir maliyet muhasebesi bölümünün varlığı, gider (masraf) yeri ayrımı yapma durumları, mamul fiyatlandırma politikaları, birleşik ve yan mamul üretimi ve maliyetlemesi, fire maliyetlerinin dağıtımı, 
planlama ve gider kontrolünde kullandıkları maliyet sistemleri, bütçe hazırlama durumları, karlılık analiz yapma durumları, üretim faktörlerinin birim maliyetteki dağılımı gibi maliyet muhasebe kullanım düzeylerini tespit etmeye yönelik sorular sorulmuştur.

Tokat ticaret ve sanayi odası verilerine göre Tokat ilinde üretim, hizmet ve ticari işletme olarak 304 tane anonim, 986 tane limitet şirket faaliyette bulunmaktadır. Tokat merkez ve ilçelerindeki organize sanayi bölgelerinde toplam 157 tane üretim işletmesi bulunmaktadır. Oda kayıtlarında işletmeler üretim, hizmet ve ticaret ayrımı yapılmadan kaydedildiği için toplam anonim ve limitet şirket sayıları kullanıldı.

Verilerin elde edilmesi için anket önce e posta yoluyla işletmelere gönderilmiştir. Ancak yeterli sayıda geri dönüş olmadığı için yüz yüze yöntem kullanılmıştır. Anket sorularının cevaplandırılması için 72 tane işletmenin genel müdür ve müdür yardımcılarıyla görüşülmüş, 57 tane işletmedeki yönetim kadrosunda yer alan genel müdür, müdür, müdür yardımcısı, muhasebe müdürü ve imalat müdürü tarafından cevaplamıştır. Araştırmada elde edilen veriler SPSS 19 programı kullanılarak analiz edilmiştir.

\subsection{Araştırmanın Sınırları}

Araştırma, Tokat merkez ve ilçelerindeki üretim işletmelerine uygulanmıştır. Araştırma için hizmet ve ticari işletmeler uygulama dışı bırakılmıştır. Tokat ilinde faaliyette bulunan toplam 1090 işletmeden, 57 adet üretim işletmesi olan anonim ve limitet şirket ile sınırlanmıştır.

\section{Araştırmanın Bulguları}

Araştırmadan elde edilen bulgular, anket uygulanan işletmeye ait genel bilgilerle maliyet muhasebesi kullanma düzeyine ilişkin bilgilerden oluşmaktadır. Araştırmadan elde edilen bulgular şu şekildedir;

Araştırmaya katılan işletmeleri, toprak sanayi, inşaat-hazır beton, orman ürünleri, gıda, metal-demir, tekstil fabrikaları olarak sınıflandırılmıştır. Araştırmaya katılan işletmelerin sektörel dağılımı Tablo 1'de gösterilmiştir.

Tablo 1. Sektörel dağılım

\begin{tabular}{lcc}
\hline Sektör & Frekans & Yüzde (\%) \\
\hline Toprak Sanayi & 13 & 23 \\
İnşaat, Hazır Beton & 8 & 14 \\
Orman Ürünleri & 5 & 9 \\
G1da & 12 & 21 \\
Metal, Demir & 5 & 9 \\
Tekstil & 14 & 25 \\
Toplam & 57 & 100 \\
\hline
\end{tabular}

Tablo 1'de görüldüğü üzere anket uygulanan işletmelerin \%25'i tekstil (çorap, penye, kot fabrikaları), \%23'ü toprak sanayi (tuğla ve kiremit fabrikaları), \%21'i gıda (şeker, süt, peynir, bitkisel ürün, yaprak, un) \%14'ü inşaat, hazır beton, \%9'u orman ürünleri (okul sırası, ağaç kaplama), metal, demir (ofis mobilyası, zirai alet) işletmelerinden oluşmaktadır. Tokat merkez ve ilçelerinde daha fazla sayıda tekstil, toprak sanayi, inşaat, gıda işletmeleri bulunduğu için anket uygulanan işletmelerin dağılımı tablo 1'deki gibi olmuştur. Araştırmaya katılan işletmelerin hukuki yapıları Tablo 2'de gösterilmiştir.

Tablo 2. İşletmelerin hukuki yapıları

\begin{tabular}{lcc}
\hline Hukuki Yapıları & Frekans & Yüzde $(\%)$ \\
\hline Anonim & 30 & 53 \\
Limited & 27 & 47 \\
Toplam & 57 & 100 \\
\hline
\end{tabular}


Tablo 2'de görüldüğg̈ üzere anketin uygulandığg işletmelerin \%53’ü anonim, \%47'si limited şirket statüsündedir. Anketi dolduran yetkililerin işletme yönetimdeki pozisyonu Tablo 3'te gösterilmiştir.

Tablo 3. Anketi dolduranların görevleri

\begin{tabular}{lcc}
\hline Posizyon & Frekans & Yüzde (\%) \\
\hline Genel Müdür & 12 & 21 \\
Müdür Yrd & 5 & 9 \\
Muhasebe Mdr & 37 & 65 \\
Üretim Mdr & 3 & 5 \\
Toplam & 57 & 100 \\
\hline
\end{tabular}

Tablo 3’te görüldüğü üzere anketi dolduran yetkililerin $\% 65$ 'i muhasebe müdürü, \%21'i genel müdür, \%9'u müdür yardımcısı ve \%5'i üretim müdürüdür. Anketi dolduran yetkililerin eğitim durumları Tablo 4'te gösterilmiştir.

Tablo 4. Anketi dolduranların eğitim durumları

\begin{tabular}{lcc}
\hline Eğitim durumları & Frekans & Yüzde (\%) \\
\hline Lisans üstü & 3 & 5 \\
Lisans & 20 & 35 \\
Önlisans & 22 & 39 \\
Lise & 12 & 21 \\
Toplam & 57 & 100 \\
\hline
\end{tabular}

Tablo 4'te görüldüğ̈̈ üzere anketi dolduran yöneticilerin \%39'u önlisans, \%30’u lisans, $\% 21$ 'i lise ve sadece \%3'ü yüksek lisans seviyesinde eğitime sahiptir. Anketi dolduran yöneticilerin maliyet muhasebesi ile ilgili ders alma durumları Tablo 5'te gösterilmiştir.

Tablo 5. Maliyet muhasebesi ile ilgili ders alma durumları

\begin{tabular}{lcc}
\hline & Frekans & Yüzde (\%) \\
\hline Evet & 13 & 22 \\
Hayır & 44 & 78 \\
Toplam & 57 & 100 \\
\hline
\end{tabular}

Tablo 5'de görüldüğ̈̈ üzere anketi dolduran yöneticilerin \%78`i maliyet muhasebesiyle ilgili bir dersi almadığını, sadece \%22'si maliyet muhasebesiyle ilgili ders aldıkları cevabını vermişlerdir. Araştırmaya katılan işletmelerin maliyetlerin kaydedilmesinde kullandıkları maliyet grubu Tablo 6'da gösterilmiştir.

Tablo 6. İşletmelerin kullandığı maliyet grubu

\begin{tabular}{lcc}
\hline Maliyet grubu & Frekans & Yüzde (\%) \\
\hline $7 / \mathrm{a}$ & 57 & 100 \\
$7 / \mathrm{b}$ & - & \\
Toplam & 57 & 100 \\
\hline
\end{tabular}

Tablo 6'da görüldüğü üzere araştırmaya katılan işletmelerin tümü maliyetlerin kaydedilmesinde 7/a maliyet hesap grubunu kullanmaktadır. Araştırmaya katılan işletmelerin üretim faaliyetinde bulundukları süreler Tablo 7'de gösterilmiştir. 
Tablo 7. Üretim faaliyetinde bulunulan süreler

\begin{tabular}{lcc}
\hline Süre (Y11) & Frekans & Yüzde (\%) \\
\hline $1-5$ & 6 & 11 \\
$6-10$ & 8 & 14 \\
$11-15$ & 7 & 12 \\
$16-20$ & 4 & 7 \\
20 ve üzeri & 32 & 56 \\
Toplam & 57 & 100 \\
\hline
\end{tabular}

Tablo 7'de görüldüğü üzere işletmelerin, \%56's1 20 yıl ve üzeri, \%14'ü 6-10 y11, \%12'si 11-15 yıl, \%7'si 16-20 yıl zaman aralığında üretim faaliyetinde bulunmaktadırlar. Araştırmaya katılan işletmelerin çalışan sayıları Tablo 8'de gösterilmiştir.

Tablo 8. İşletmelerin çalışan sayıları

\begin{tabular}{lcc}
\hline Çalışan Sayıs1 & Frekans & Yüzde (\%) \\
\hline 50 'den az & 25 & 44 \\
$50-100$ & 11 & 19 \\
$101-250$ & 10 & 18 \\
$251-500$ & 5 & 9 \\
$501-750$ & 6 & 11 \\
Toplam & 57 & 100 \\
\hline
\end{tabular}

Tablo 8'de görüldügü üzere işletmelerin \%44'ü 50 kişiden az, \%19'u 50-100 aras1, \%18'i 101-250, \%11'i 501-750, \%9'u 251-500 arası çalışana sahiptir. Çalışanların sektörlere göre dağ 1 lımı Tablo 9'da gösterilmiştir.

Tablo 9. Çalışan sayısının sektörel dağılımı

\begin{tabular}{lccccccc}
\hline & $\begin{array}{c}\text { Toprak } \\
\text { Sanayi }\end{array}$ & $\begin{array}{c}\text { İnşaat, } \\
\text { Hazır } \\
\text { Beton }\end{array}$ & $\begin{array}{c}\text { Örman } \\
\text { Ürünleri }\end{array}$ & Gıda & $\begin{array}{c}\text { Metal } \\
\text { Demir }\end{array}$ & Tekstil & Toplam \\
\hline 50 'den az & & 8 & 3 & 9 & 5 & & 25 \\
$50-100$ & 8 & & 2 & 2 & & 1 & 11 \\
$101-250$ & 5 & & & & & 5 & 10 \\
$251-500$ & & & & 1 & & 5 & 6 \\
$501-750$ & 13 & 8 & 5 & 12 & 5 & 14 & 57 \\
Toplam & & & & & & & \\
\hline
\end{tabular}

Çalışanların sektörlere göre dağılımı için hazırlanan Tablo 9'da görüldüğü üzere en fazla çalışan tekstil sektöründedir. Çalışan sayısı 501-750 arası olan işletmelerin 5 tanesi tekstil 1 tanesi gıda sektöründe yer almaktadır. Yine 251-500 arası çalışanların tekstil sektöründe olduğu, toprak ve orman ürünleri sanayinde çalışanların 101-250 arası çalışan olduğu, inşaat, hazır beton, metaldemir olan gruptaki işletmelerin çalışan sayısı 50'nin altında olduğu tespit edilmiştir. Araştırmada işletmelere ayrı bir maliyet muhasebesi bölümünün olup almadığı sorusu sorulmuş ve alınan cevaplar Tablo 10' da gösterilmiştir.

Tablo 10. Ayrı maliyet muhasebesi bölümünün bulunması

\begin{tabular}{lcc}
\hline & Frekans & Yüzde \\
\hline Evet & 17 & 30 \\
Hayır & 40 & 70 \\
Toplam & 57 & 100 \\
\hline
\end{tabular}

Tablo 10'da görüldüğü üzere işletmelerin büyük çoğunluğunda (\%70'inde) ayrı bir maliyet muhasebesi bölümü bulunmamaktadır. Maliyet muhasebesi bölümü olmayan işletmelerde maliyet verilerinin elde edilmesi finansal muhasebe birimi tarafindan yapılmaktadır. Tabi ayrı bir maliyet muhasebe biriminin olması işletmelerin maliyet verilerinin tespit edilmesi 
ve maliyetlerin kontrol edilmesi için önemlilik arz eder. Ayrı bir maliyet muhasebe bölümü oluşturan işletmelerin sektörlere göre dağılımı Tablo 11'de gösterilmiştir

Tablo 11. Maliyet muhasebesi bölümü olan sektör dağılımı

\begin{tabular}{lccccccc}
\hline & $\begin{array}{l}\text { Toprak } \\
\text { Sanayi }\end{array}$ & $\begin{array}{c}\text { İnşaat, } \\
\text { Hazır } \\
\text { Beton }\end{array}$ & $\begin{array}{c}\text { Orman } \\
\text { Ürünleri }\end{array}$ & G1da & $\begin{array}{c}\text { Metal, } \\
\text { Demir, }\end{array}$ & Tekstil & Toplam \\
\hline Evet & 1 & 1 & 1 & 5 & 1 & 8 & 17 \\
Hayır & 12 & 7 & 4 & 7 & 4 & 6 & 40 \\
Toplam & 13 & 8 & 5 & 12 & 5 & 14 & 57 \\
\hline
\end{tabular}

Tablo 11'de görüldüğ̈̈ üzere gıda ve tekstil fabrikalarında ayrı maliyet muhasebe bölümünün oluşturulmuş olması diğer işletmelere göre daha fazladır. Araştırmada işletmelere maliyet hesaplaması yapılırken gider yeri ayrımı yapma durumu sorulmuş ve alınan cevaplar Tablo 12'de gösterilmiştir.

Tablo 12. Ayrı gider yeri bulunması

\begin{tabular}{lcc}
\hline & Frekans & Yüzde (\%) \\
\hline Evet & 36 & 63 \\
Hayır & 21 & 37 \\
Toplam & 57 & 100 \\
\hline
\end{tabular}

Tablo 12'de görüldüğü üzere işletmelerin \%63'ü gider yeri ayrımı yapmakta, \%37'si ayrım yapmamaktadır. Gider yeri ayrımı yapan işletmelerin sektörlere göre dağılımı Tablo 13 'te gösterilmiştir.

Tablo 13. Gider yeri ayrımının sektörel dağılımı

\begin{tabular}{lccccccc}
\hline & $\begin{array}{c}\text { Toprak } \\
\text { Sanayi }\end{array}$ & $\begin{array}{c}\text { İnşaat, Hazır } \\
\text { Beton }\end{array}$ & $\begin{array}{c}\text { Orman } \\
\text { Ürünleri }\end{array}$ & Gida & $\begin{array}{c}\text { Metal } \\
\text { Demir }\end{array}$ & Tekstil & Toplam \\
\hline Evet & 3 & 5 & 3 & 8 & 3 & 14 & 36 \\
Hayır & 10 & 3 & 2 & 4 & 2 & & 21 \\
Toplam & 13 & 8 & 5 & 12 & 5 & 14 & 57 \\
\hline
\end{tabular}

Tablo 13’te görüldüğü üzere gıda ve tekstil firmalarının tamamında gider yeri ayrımının bütün işletmelerde yapıldığı, diğer sektörlerde hem ayrım yapan hem de ayrım yapmayan işletmelerin olduğu tespit edilmiştir. Ayrıca, toprak sanayideki işletmelerin büyük çoğunluğu gider yeri ayrımı yapmadığı göze çarpmaktadır. İşletmelerin birim maliyetin tespit edilmesinde üretim yönetimine göre kullanılan sistemleri safha, sipariş ve karma maliyet yöntemi açısından değerlendirilmiş ve elde edilen sonuçlar Tablo 14'te gösterilmiştir.

Tablo 14. Üretim yönetimine göre maliyet sistemleri

\begin{tabular}{lcc}
\hline & Frekans & Yüzde $(\%)$ \\
\hline Safha maliyetlime & 31 & 54 \\
Sipariş maliyetlime & 14 & 25 \\
Karma & 12 & 21 \\
Toplam & 57 & 100 \\
\hline
\end{tabular}

Tablo 14'te görüldüğü üzere işletmelerin \%54'ü safha, \%25'i sipariş ve \%21'i karma maliyet sistemi kullandıkları cevabını vermişlerdir. İşletmelerin büyük çoğunluğu safha maliyet sistemini kullanmaktadır. Kullanılan maliyet sistemlerinin sektörlere göre dağılımı Tablo 15 'te gösterilmiştir. 
Tablo 15. Kullanılan maliyet sistemlerinin sektörel dağ 11 ımı

\begin{tabular}{lccccccc}
\hline & $\begin{array}{c}\text { Toprak } \\
\text { Sanayi }\end{array}$ & $\begin{array}{c}\text { İnşaat, Hazır } \\
\text { Beton }\end{array}$ & $\begin{array}{c}\text { Örman } \\
\text { Ürnleri }\end{array}$ & Gida & $\begin{array}{c}\text { Metal } \\
\text { Demir }\end{array}$ & Tekstil & Toplam \\
\hline Safha & 13 & 3 & 2 & 9 & & 4 & 31 \\
Sipariş & & 3 & & 3 & 5 & 3 & 14 \\
Karma & & 2 & 3 & & & 7 & 12 \\
Toplam & 13 & 8 & 5 & 12 & 5 & 14 & 57 \\
\hline
\end{tabular}

Tablo 15'te görüldüğü üzere toprak sanayideki işletmelerin tamamı safha maliyet sistemini, metal, demir işletmelerinin tamamı sipariş maliyet sistemini, diğer işletmelerinde karma maliyet sistemini kullandıkları tespit edilmiştir. Araştırmada işletmelere, mamul maliyetlerinin tespitinde kullanılan rakamların fiili veya önceden belirlenmiş rakamların kullanma durumları sorulmuş verilen cevaplar Tablo 16' da gösterilmiştir.

Tablo 16. Fiili veya önceden belirlenmiş maliyet yöntemleri

\begin{tabular}{lcc}
\hline & Frekans & Yüzde (\%) \\
\hline Fiili maliyet yöntemi & 39 & 68 \\
Standart Maliyet Yöntemi & 1 & 2 \\
Tahmini Maliyet Yöntemi & 17 & 30 \\
Toplam & 57 & 100 \\
\hline
\end{tabular}

Tablo 16'da görüldüğü üzere işletmelerin \%68'i fiili maliyetlime, \%30’u tahmini maliyetlime, \%2'si standart maliyet yöntemini kullanmaktadırlar. Araştırmada işletmelere stok değerlemede kullandıkları yöntemleri FIFO, Ortalama maliyet, Piyasa fiyatı ve diğer yöntemler şeklinde sorulmuş ve elde edilen cevaplar Tablo 17'de gösterilmiştir.

Tablo 17. Stok değerleme yöntemleri

\begin{tabular}{lcc}
\hline Stok Değerleme Yöntemi & Frekans & Yüzde (\%) \\
\hline Ortalama & 42 & 74 \\
Piyasa Fiyatı & 13 & 23 \\
Fifo & 2 & 4 \\
Diğer & & 0 \\
Toplam & 57 & 100 \\
\hline
\end{tabular}

Tablo 17 'den görüldüğü üzere işletmelerin $\% 74$ 'ü ortalama maliyet yöntemini, \%23'ü piyasa fiyatı yöntemini, \%4'ü Fifo yöntemini stok değerlemede kullanmaktadırlar. Tablo 17'de yer alan yöntemlerin (ortalama yöntem, fifo yöntemi, piyasa fiyatı yöntemi) dışında başka bir yöntem kullanılmamıştır. Araştırmada işletmelere mamul fiyatlama yaparken kullandıkları yöntemi maliyet + kar, piyasa fiyatı, talebe göre ve diğer yöntemler şeklinde sorulmuş, verilen cevaplar Tablo 18'de gösterilmiştir.

Tablo 18. Mamul fiyatlama yöntemleri

\begin{tabular}{lcc}
\hline Fiyatlama Yöntemi & Frekans & Yüzde (\%) \\
\hline Maliyet +Kar Yöntemi & 37 & 65 \\
Piyasa Fiyatı Yöntemi & 17 & 30 \\
Talebe göre fiyatlama & & 5 \\
Yöntemi & 3 & 0 \\
Diğer & 57 & 100 \\
Toplam & & \\
\hline
\end{tabular}

Tablo 18'de görüldüğü üzere elde edilen cevaplardan işletmelerin çoğu (\%65'i) maliyet + kar yöntemine göre, \%30'u piyasa fiyatı yöntemine göre, $\% 5$ 'i talebe göre fiyatlama yöntemini kullanmaktadırlar. Araştırmada işletmelere esas üretim yerlerindeki maliyetlerin mamullere dağıtılmasında kullanılan faaliyet hacminin ne / neler olduğu sorusuna verilen cevaplar Tablo 19'da gösterilmiştir. 
Tablo 19. Maliyet dağıtımında kullanılan dağıtım anahtarları

\begin{tabular}{lcc}
\hline & Frekans & Yüzde (\%) \\
\hline Üretim Miktarı & 56 & 62 \\
Makine Saati & 5 & 6 \\
Direkt İşilik Saati & 8 & 9 \\
Direkt İlk Madde ve Malzeme & & \\
Maliyeti & 11 & 12 \\
Direkt İşçilik Maliyeti & 10 & 11 \\
Toplam & 90 & 100 \\
\hline
\end{tabular}

Tablo 19'da görüldüğü üzere işletmelerin esas üretim yerlerindeki maliyetlerin mamullere yüklenmesinde $\% 62$ 'lik oranla en fazla üretim miktarını kullandığ 1 , direkt ilk madde ve malzeme maliyeti $\% 12$, direkt işçilik maliyeti $\% 11$, direkt işçilik saati $\% 9$ ve makine saati $\% 6$ oranında dağıtım anahtarı olarak kullandıkları tespit edilmiştir. İşletmelerin birden fazla faaliyet hacmini maliyet dağıtımda kullanabildiği için frekans 90 olarak bulunmuştur. Araştırmaya katılan işletmelerin bütçe hazırlayıp hazırlamadıkları sorulmuş, alınan cevaplar Tablo 20'de gösterilmiştir.

Tablo 20. Bütçe hazırlama durumları

\begin{tabular}{lcc}
\hline & Frekans & Yüzde (\%) \\
\hline Evet & 40 & 70 \\
Hayır & 17 & 30 \\
& 57 & 100 \\
\hline
\end{tabular}

Tablo 20'de görüldüğü üzere araştırmaya katılan işletmelerin \%70 bütçe hazırladıklarını \%30'u hazırlamadıkları cevabını vermişlerdir. Bütçe hazırlayan işletmelerin hangi tür bütçe hazırladıkları sorusuna verdikleri cevaplar Tablo 21 'de gösterilmiştir.

Tablo 21. Hazırlanan bütçe türleri

\begin{tabular}{lcc}
\hline Bütçe Türleri & Frekans & Yüzde (\%) \\
\hline Satış Bütçesi & 13 & 14 \\
Üretim Bütçesi & 40 & 42 \\
Satın alma Bütçesi & 19 & 20 \\
Nakit Bütçesi & 14 & 15 \\
Yatırım Bütçesi & 2 & 2 \\
Pazarlama Bütçesi & 7 & 7 \\
Toplam & 95 & 100 \\
\hline
\end{tabular}

Tablo 21 'de görüldüğü üzere işletmelerin, \%42'si üretim, \%20'si satın alma, \%15'i nakit, $\% 14$ 'ü satış, \%7'si pazarlama ve \%2'side yatırım bütçesi hazırladıkları cevabını vermiştir. İşletmelerin birden fazla bütçe hazırladıkları için frekans işletme sayısından fazla çıkmıştır. Araştırmada işletmelere her mamul, her bölüm veya hem mamul hem bölüm için ayrı ayrı karlılık analizleri yapıp yapmadıkları sorusuna verdikleri cevaplar Tablo22'te gösterilmiştir.

Tablo 22. Karl111k analizi

\begin{tabular}{lcc}
\hline & Frekans & Yüzde (\%) \\
\hline Her Mamulün Karlılığını Ayrı Ayrı hesaplama & 37 & 62 \\
Her Bölümün Karlılığını Ayrı Ayrı hesaplama & 1 & 2 \\
Hem Bölümün Hem Mamulün Karlılığını Ayrı Ayrı hesaplama & 16 & 27 \\
Karlılık analizi Yapmıyoruz & 6 & 10 \\
Toplam & 60 & 100 \\
\hline
\end{tabular}

Tablo 22'de görüldüğü üzere işletmelerin \%62'si her mamulün karlılığını ayrı ayrı hesapladığını, \%27'si hem bölümün hem de mamulün karlılığını ayrı ayrı hesapladığını, \%’2 her bölümün karlılı̆̆ını ayrı ayrı hesaplamaktadır. İşletmelerin \%10’u karlılık analizi yapmamaktadır. 
Araştırmada işletmelere yan ve birleşik mamul üretiyor musunuz sorusu sorulmuş alınan cevaplar Tablo 23'te gösterilmiştir.

Tablo 23. Yan ve bileşik mamul üretme durumu

\begin{tabular}{lcc}
\hline & Frekans & Yüzde (\%) \\
\hline Evet & 11 & 19 \\
Hayir & 46 & 81 \\
Toplam & 57 & 100 \\
\hline
\end{tabular}

Tablo 23'te görüldüğü üzere araştırmaya katılan işletmelerin \%19'unda yan veya bileşik mamul üretilmekte, \%81'inde üretilmemektedir. Gıda sektöründeki işletmeler yan ve birleşik mamul üretiyoruz sorusuna evet cevabı verirken diğer sektörlerdeki işletmeler hayır cevabı vermişlerdir. Birleşik ve yan mamul üreten işletmelerin birleşik ve yan mamul maliyetlerinin dağıtımını nasıl yapıyorsunuz sorusuna verdikleri cevaplar Tablo 24'te gösterilmiştir.

Tablo 24. Birleşik ve yan mamul maliyetlerin dağıtım yöntemi

\begin{tabular}{lcc}
\hline & Frekans & Yüzde (\%) \\
\hline Üretim Miktarını Esas Alan Yöntem & 9 & 82 \\
Satış Değerini Esas Alan Yöntem & 2 & 18 \\
Tahmini Net Gerçekleşebilir Değer Yöntemi & & \\
$\begin{array}{l}\text { Brüt Kar Oranı } \\
\text { Toplam }\end{array}$ & 11 & 100 \\
\hline
\end{tabular}

Tablo 24'te görüldüğü üzere işletmelerin \%82'si üretim miktarını esas alan yöntemi, \%18'i satış değerini esas alan yöntemi kullanmaktadır. Diğer yöntemler işletmeler tarafından kullanılmamaktadır. Araştırmaya katılan işletmelerin maliyetleri hangi aralıklarla hazırlıyorsunuz sorusuna verdikleri cevaplar Tablo 25'te gösterilmiştir.

Tablo 25. Maliyet hesaplarının hazırlanma zaman aralığı

\begin{tabular}{lcc}
\hline & Frekans & Yüzde (\%) \\
\hline Aylık & 22 & 39 \\
3 Aylık & 24 & 42 \\
6 Aylk & 0 & 0 \\
1 Y1llk & 11 & 19 \\
Toplam & 57 & 100 \\
\hline
\end{tabular}

Tablo 25'te görüldüğü üzere işletmelerin \%39'u aylık, \%42'si 3 aylık, \%19'u yıllık olarak maliyetleri hazırlamaktadır. Altı aylık maliyetleri hazırlayan işletme bulunmamaktadır. Araştırmaya katılan işletmelere maliyetlerin kapsamına göre kullandıkları yöntemin, tam maliyet, değişken maliyet, normal maliyet ve direkt maliyet yöntemlerinden hangisi olduğu sorusuna verdikleri cevaplar tablo 26 ' da gösterilmiştir.

Tablo 26. Maliyet yöntemleri

\begin{tabular}{lcc}
\hline & Frekans & Yüzde (\%) \\
\hline Tam maliyet Yöntemi & 42 & 73 \\
Değişken Maliyet Yöntemi & 5 & 9 \\
Normal Maliyet Yöntemi & 8 & 14 \\
Asal Maliyet Yöntemi & 2 & 4 \\
Toplam & 57 & 100 \\
\hline
\end{tabular}

Tablo 26'da görüldüğü üzere işletmelerin çoğu (73'ü) tam maliyet yöntemini, \%14'ü normal maliyet yöntemini, \%9'u değişken maliyet yöntemini, \%4'ü asal maliyet yöntemini kullanarak maliyet hesaplaması yapmaktadırlar. Araştırmaya katılan işletmelere Tablo 27'de yer alan maliyet muhasebesini kullanma amaçlarını, öncelik sırasına göre sıralamaları istenmiş, 1. Öncelik cevabını verenler Tabloda 27'de gösterilmiştir. 
Tablo 27. Maliyet muhasebesini 1 öncelikte kullanma amaçları

\begin{tabular}{lcc}
\hline & Frekans & Yüzde (\%) \\
\hline Mamul Maliyetlerini hesaplamak için & 37 & 65 \\
Mamul Fiyatlandırmak İçin & 7 & 12 \\
Bütçe hazırlamaya yardımcı olması için & 5 & 9 \\
Maliyetlerin kontrolüne yardımcı olması için & 2 & 4 \\
Maliyet azaltma çalışmalarına yardımcı olması için & 6 & 11 \\
Toplam & 57 & 100 \\
\hline
\end{tabular}

Tablo $27^{\prime}$ de görüldüğü üzere işletme yöneticilerinin \%65'i mamul maliyetlerini hesaplamak için, \%12'si mamul fiyatlandırmak için, \%11 maliyetleri azaltmada yardımcı olması için, \%9'u bütçe hazırlamaya yardımcı olması için, \%4'ü maliyetlerin kontrolüne yardımcı olması için maliyet muhasebesini birinci öncelik olarak kullandıkları cevabını vermişlerdir. Araştırmaya katılan işletmelere fireyi dikkate allyor musunuz sorusuna verdikleri cevaplar Tablo 28 'de gösterilmiştir.

Tablo 28. Fireyi dikkate alma durumu

\begin{tabular}{lcc}
\hline & Frekans & Yüzde (\%) \\
\hline Evet & 47 & 82 \\
Hayır & 10 & 18 \\
Toplam & 57 & 100 \\
\hline
\end{tabular}

Tablo 28'de görüldüğü üzere araştırmaya katılan işletmelerin \%72'si fireyi dikkate aldığını, \%28'i dikkate almadığını ifade etmişlerdir. Fireyi dikkate alan işletme yöneticilerinin \%84'ü fire maliyetini mamule yansıttıklarını, \%16's1 dönem giderleri arasında gösterdikleri cevabını vermişlerdir. Araştırmaya katılan işletmelere üretilen mamullerin içindeki direkt ilk madde ve malzeme, direkt işçilik ve genel üretim maliyetlerinin payları sorulmuş, verilen cevaplar Tablo 28'de gösterilmiştir.

Tablo 29. Maliyet etkenlerinin mamuldeki payları

\begin{tabular}{lcccccc}
\hline & \multicolumn{2}{c}{ DİMM } & \multicolumn{2}{c}{ Direkt İşçilik } & \multicolumn{2}{c}{ GÜM } \\
& Frekans & Yüzde & Frekans & Yüzde & Frekans & Yüzde \\
\hline$\% 1-10$ aras1 & 11 & 19 & 15 & 26 & 9 & 16 \\
$\% 11-20$ aras1 & 2 & 4 & 14 & 24 & 13 & 23 \\
$\% 21-30$ aras1 & & & 13 & 23 & 20 & 35 \\
$\% 31-40$ aras1 & 5 & 9 & 2 & 4 & 2 & 4 \\
$\% 41-50$ aras1 & 8 & 14 & 13 & 23 & 2 & 4 \\
$\% 51-60$ aras1 & 13 & 23 & & & 11 & 19 \\
$\% 61-70$ aras1 & 10 & 18 & & & & \\
$\% 71-80$ aras1 & 2 & 4 & & & & \\
$\% 81-90$ aras1 & 4 & 7 & & & & \\
$\% 91-100$ aras1 & 2 & 4 & & & & \\
Toplam & 57 & 100 & 57 & 100 & 57 & 100 \\
\hline
\end{tabular}

Tablo 29'da görüldüğü üzere işletmelerin direkt ilk madde ve malzeme maliyetinin genel ortalaması \%50'den daha fazladır. Ankete katılan işletmelerin \%23'nün birim maliyetteki payı \%51-60, \%18'nin 61-70, \%4'ü \%91-100 aralığındadır. Sektör olarak toprak \%1-20, tekstil \%3060 , gida \%40-80, orman \%60-90, metal, demir \%50-70, inşaat, hazır beton \%50-70, un fabrikalarında \%80-100 aralığında direkt ilk madde ve malzeme maliyeti olan işletmeler bulunmaktadır. Toprak sanayinde en düşük malzeme maliyetinin ortaya çıkmasının nedeni hammadde maliyetinin düşük olmasıdır.

Direkt işçilik ve genel üretim maliyeti açısından işletmelerin büyük çoğunluğunun birim maliyetlerindeki payı \%1-30 aralığındadır. Direkt işçilik maliyeti açısından ankete katılan işletmelerin \%26'sının birim maliyetteki payı \%1-10, \%24'nün \%11-20, \%23'nün \%21-30, 
\%23'nün \%41-50 aralığındadır. Sektör olarak un fabrikaları \%1-10, Orman ürünleri \%1-20, inşaat, hazır beton \%1-20, gida \%1-20, metal, demir \%11-30, tekstil \%11-40, toprak \%41-50 aralığında direkt işçilik maliyeti olan işletmeler bulunmaktadır.

Genel üretim maliyeti açısından ankete katılan işletmelerin \%35'nin birim maliyetteki genel üretim maliyetinin pay1 \%21-30, \%23'nün \%11-20, \%19'nun \%51-60, \%16'nın \%1-10 aralığındadır. Sektör olarak, un fabrikaları \%1-10, inşaat, hazır beton \%1-30, orman ürünleri \%120 , gida, tekstil \%11-30, metal \%21-30, toprak \%51-60 aralığında genel üretim maliyeti olan işletmeler bulunmaktadır.

\section{Sonuç}

Tokat merkez ve ilçelerinde faaliyette bulunan üretim işletmelerinde maliyet muhasebesi kullanım düzeyi ile ilgili yapılan araştırmadan elde edilen bulgular şöyle özetlenebilir:

$\checkmark$ Tokatta üretim işletmelerin çoğunluğu tekstil (çorap, kot, penye), toprak sanayi (Tuğla ve Kiremit), gıda (şeker, peynir, süt, yaprak), inşaat ve hazır beton ve orman ürünleri sektöründe faaliyet göstermektedirler.

$\checkmark$ İşletmelerin büyük çoğunluğunun hukuki yapısı anonim şirket statüsündedir.

$\checkmark$ İşletmeler TDHP'da 7 / A maliyet hesap grubunu kullanmaktadırlar

$\checkmark$ Çalışan sayısı bakımından en fazla çalışan tekstil, gıda, tuğla ve orman ürünleri sektöründeki işletmelerdedir. Tekstli ve gıda sektöründe 750 kişiye kadar çalışanı olan işletmeler bulunmaktadır.

$\checkmark$ İşletmelerin \%70'inde ayrı bir maliyet muhasebesi bölümü bulunmamaktadır.

$\checkmark$ İşletmelerin \%63'ü gider yeri ayrımı yapmaktadır.

$\checkmark$ İşletmelerin \%54'ü safha maliyet sistemi, \%25'i sipariş maliyet sistemini, \%21'i karma maliyet sistemini kullanılmaktadır.

$\checkmark$ Maliyetlerin tespit edilmesinde işletmelerin \%68'i fiili maliyet yöntemini, \%30'u tahmini maliyet yöntemini, \%2'si standart maliyet yöntemini kullanmaktadır.

$\checkmark$ Stok değerlemede, işletmelerin \%74'ü ortalama maliyet yöntemini, \%23'ü piyasa fiyat1 yöntemini, \%4'ü fifo yöntemini tercih etmektedir.

$\checkmark$ Mamul fiyatlamada işletmelerin \%65'i maliyet + kar yöntemini, \%30’u piyasa fiyatı yöntemini, \%5'i talebe göre fiyatlama yöntemini kullanmaktadır.

$\checkmark$ Esas gider yelerindeki üretim maliyetlerinin mamullere yüklenmesinde faaliyet hacmi olarak \%62'i üretim miktarını, \%12'si direkt ilk madde ve malzeme maliyetini, \%11'i direkt işçilik maliyetini, \%9'u direkt işçilik saatini, \%6\%sı makine saatini tercih etmektedir.

$\checkmark$ İşletmelerin \%70'i bütçe hazırlamakta, bütçe olarak \%42'si üretim, \%20'si satın alma, \%15'i nakit, \%14'ü satış, \%7'si pazarlama, \%2'si yatırım bütçesi hazırlamaktadır.

$\checkmark$ İşletmelerin \%62'si her mamulün karlılığını ayrı ayrı, \%27'si hem bölümün hem mamulün karlılığını ayrı ayrı, \%2'si her bölümün karlılığını hesaplamakta, \%10'da karlılık analizi yapmamaktadır.

$\checkmark$ İşletmelerin \%19'u birleşik ve yan mamul üretmekte, birleşik ve yan mamulün maliyetinin hesaplanmasında \%82'si üretim miktarını esas alan yöntemi, \%18'i satış değerini esas alan yöntemi tercih etmektedir.

$\checkmark$ İşletmelerin \%42'si 3 aylık, \%39'u aylık, \%19'u yıllık olarak maliyetlerini hazırlamaktadır. 
$\checkmark$ Maliyetlerin kapsamına göre işletmelerin \%73’ü tam maliyet yöntemini, \%14'ü normal maliyet yöntemini, \%9’u değişken maliyet yöntemini, \%4'ü direkt maliyet yöntemini tercih etmektedir.

$\checkmark$ Maliyet muhasebesini kullanmaktaki birincil amaç mamul maliyetlerini hesaplamaktır.

$\checkmark$ İşletmelerin \%72'si fire dikkate almaktadır.

$\checkmark$ Üretim maliyetlerinden direkt ilk madde ve malzeme maliyeti, maliyet etkenleri içerisinde en önemli etken olduğu tespit edilen bulgular arasındadır.

Yukarıda çıkan sonuçlarda görüldüğü gibi işletmelerin yönetim kararlarında önemli etkisi olan maliyet muhasebesi kullanma düzeylerinde ișletmeler arasında farklılık olmaktadır. İşletmelerin maliyet muhasebesinden istenen faydayı sağlayabilmeleri için ayrı bir maliyet muhasebesi bölümünü kurmaları gerekmektedir. Ayrıca yöneticilerin maliyet muhasebesi eğitim alma oranında düşük olduğu tespit edilmiştir. Yöneticilerin maliyet muhasebesi verilerinden daha fazla faydalanmaları için maliyet muhasebesi ile ilgili eğitim programları veya kurslara kat1lmalar1 önerilmektedir.

$\mathrm{Bu}$ alanda çalışma yapacak araştırmacılar, maliyet muhasebesi kullanım düzeyinin araştırılmasını sektörel bazda bir ilde veya bölgede yapılabilirler. İl bazında yapılacak araştırma ile ildeki işletmelerin maliyet muhasebesi kullanım farklılıkları tespit edilebilir. Bölgesel çapta yapılacak araştırma ile bölgedeki iller arasındaki maliyet muhasebesi kullanım düzeyi farklılıklar tespit edilebilir.

\section{Kaynaklar}

Abdioğlu, H. (2013). Maliyet muhasebesi, Bursa: Dora Yayınları.

Antony, J. ve Kumar, M. (2005). Six sigma in small- and medium-sized uk manufacturing enterprises some empirical observations, International Journal of Quality \& Reliability Management, 22 (8), 860-874.

Atamanalp, M.C., Karcioğlu, R. ve Orhan, M.S. (2000). Tekdüzen hesap planına uygun maliyet muhasebesi, Erzurum: Aktif Yayınevi.

Ayyıldı, M.S.Ü. ve Durna, Ş. (2005). Kayseri'de faaliyet gösteren işletmelerde maliyet muhasebesi kullanılma düzeyine ilişkin bir araştırma, Muhasebe ve Finansman, 27, 94-104.

Bursal, N. Ve Ercan, Y. (1997). Maliyet Muhasebesi İlkeler ve Uygulama, İstanbul: Der Yayınları.

Büyükmirza, K. (2000). Maliyet ve yönetim muhasebesi, Ankara: Barış Kitapevi

Can, A.V. (2006). Maliyet muhasebesi ders notları, Adapazarı: Sakarya Kitapevi.

Civelek, M. (2002). Maliyet muhasebesi, Ankara: Detay Yayıncılık.

Dönmez, A., Berberoğlu, P. B., Demirel, B., ve Ersoy, A. (2006). Yönetim muhasebesinin kavramsal gelişim sürecinin değerlendirilmesi, Akdeniz Üniversitesi I.I.I.B.F. Dergisi, 11, 178203

Ersoy, A., Demirel, B.U., Dönmez, A.ve Berberoğlu, B. (2006). Üretim işletmelerinde yönetim muhasebesi konularının uygulanmasına ilişkin bir araştırma, Muhasebe ve Finansman Dergisi, $32,50-60$.

Ertaş, F.C. (2016). Maliyet muhasebesi, İstanbul: Beta Yayınları.

Görmüş, A.Ş., Bulca, H. ve Yeşil, T. (2015). Yönetimin etkinliği açısından standart maliyet yönteminin uygulanması, Uşak Üniversitesi Sosyal Bilimler Dergisi, 8(2), 67-84.

http://www.tokattso.org.tr/?pnum=59\&pt=Tokat+Ekonomisi (30.08.2020). 
Mărgınean, R. (2013). the cost management by applying the standart costing method in the furniture industry, Cross-Cultural Management Journal, 15 (27), 97-105.

Özkan, A. (2006). Sanayi işletmelerinde uygulanan maliyet muhasebesi politikalarının araştırılmasi: Kayseri örneği, Marmara Üniversitesi Sosyal Bilimler Enstitüsü Öneri Dergisi, 7 (25), 107-118.

Özulucan, A. (2010). Stok muhasebesi. İstanbul: Türkmen Kitabevi.

Özulucan, A. (2019). Genel muhasebe ilkeleri ve uygulamalar, Konya: Dizgi Yayınevi.

Tanç, Ş.G. (2012). Otel işletmelerinde yönetim muhasebesi uygulamalarını tespit etmeye yönelik araştırma: Kapadokya Bölgesi örneği. NEÜ Sosyal Bilimler Enstitüsü Dergisi, 2, 170-182.

Tekşen, Ö. ve Kalkan, Y. (2012). Yönetim kararlarında muhasebe bilgi sisteminin etkisi: batı Akdeniz bölgesi'nde faaliyette bulunan mermer işletmeleri üzerine bir araştırma, $M O ̈ D A V, 14$, $127-142$.

Tugay, O. ve Akın, O. (2013). Üretim işletmelerinde maliyet muhasebesi uygulama düzeyi: Burdur' da Bir Araştırma, Afyon Kocatepe Üniversitesi İIBF Dergisi, XV (II), 469-489.

Tutkavul, K. ve Elmacı, O. (2016). Fiyatlandırma kararlarında geleneksel ve çağdaş maliyetleme sistemlerinin yeterliliklerinin karşılaştırılmasına yönelik ampirik bir çalışma, Muhasebe Bilim Dünyası Dergisi, 18 (3), 659-689.

Uyar, S. (2008). denizli'de faaliyet gösteren üretim işletmeleri'nde maliyet muhasebesi uygulamalar1, Muhasebe ve Finansman Dergisi, 38, 132-146.

Yükçü, S. ve Atağan, G. (2012). 20. Yüzyılın ilk yarısında maliyet muhasebesinin gelişimi. MUFTAV Dergisi, 2, 39-67.

Yüzbaşığlu, N. (2004). İşletmelerde stratejik yönetim ve planlama açısından stratejik maliyet yönetimi ve enstrümanları, Selçuk Üniversitesi Sosyal Bilimler Enstitü Dergisi, 12, 387-410.

\section{ETIKK ve BİLİMSEL İLKELER SORUMLULUK BEYANI}

$\mathrm{Bu}$ çalışmanın tüm hazırlanma süreçlerinde etik kurallara ve bilimsel atıf gösterme ilkelerine riayet edildiğini yazar(lar) beyan eder. Aksi bir durumun tespiti halinde Afyon Kocatepe Üniversitesi Sosyal Bilimler Dergisi'nin hiçbir sorumluluğu olmayıp, tüm sorumluluk makale yazarlarına aittir. Yazarlar etik kurul izni gerektiren çalışmalarda, izinle ilgili bilgileri (kurul adı, tarih ve sayı no) burada belirtmişlerdir. Etik Kurulu

Kurul adı: Tokat Gaziosmanpaşa Üniversitesi Sosyal ve Beşerî Bilimler Araştırmaları

Tarih:04.08.2020

No:11 